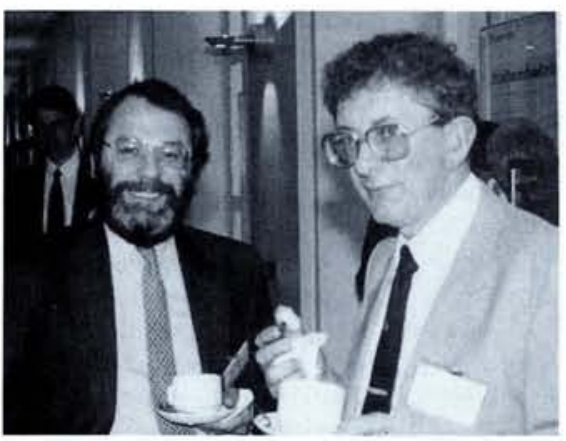

P.L. Knight, Chairman, Qúantum Optics Division, and E. Jakeman, Member, EPS Executive Committee.

Europhysics News, reviewed changes to the Editorial Board of the journal and described the editorial policy, which was to expand adiabatically while maintaining an equal balance between articles, news and topical items and Society affairs, including the semi-annual meetings listings and the Directory. This balance had been maintained over the last 12 months.

\section{Divisional Reorganization}

The recommendations of the working group on the future of the Optics Division were presented by E. Jakeman, the group's Chairman. The situation is that the Division's Board resigned on the formation of the European Optical Society (EOS, see Europhysics News 22 (1991) 92) and it was impractical to consider forming a new Board as most of the senior figures in optics were committed to the new society. However, the postal ballot of the 260 members of the Optics Division gave only 53 members in favour of the Division being dismantled. Meanwhile, some 106 members of the Division are also members of Quantum Electronics. Council felt a home was needed for optical physicists and the Executive Committee's recommendation, endorsed by Council, was to have the Optics Division taken over by the Division with the most overlap, namely Quantum Electronics, until arrangements could be finalized following consultation with other Divisions, notably Atomic and Molecular Physics, as to areas where optics activities could be expanded.

Changing the Division's name to reflect its increased scope may eventually be desirable. In any event, P.L. Knight, the Chairman of the Quantum Electronic Division, will present the recommendations to members in August.

Commenting on discussions between the Executive Committee and officers of the recently formed European Astronomical Society (EAS), M. Jacob pointed out that historically, the Astronomy and Astrophysics Division had organized the IAU conference when it was held in Europe and that there was a very active Solar Physics Section. EAS, on the other hand, is a new society representing interests well beyond physics. M. Jacob noted the interest in fostering coherent, harmonious and strong links between astronomy and astrophysi- cists whilst keeping much of the astrophysics activities within EPS. The Executive Committee had discussed the idea of having some form of joint division subject to an agreement limited in time. The immediate aim, however, was to invigorate the Division to ensure that it covered all aspects of astrophysics, during which time the Solar Physics Section would represent the Division Board pending new elections. The majority seemed in favour of M. Jacob's sug gestion that it may eventually be appropriate to change the Division's name to Astrophysics.

In closing the meeting, Professor Ricci, who retires after serving six years on the Executive Committee, remarked that the work as President was not always as gratifying as he would have liked as one could not always do what one wanted since the Society was not organized in the most effective manner. However, if one assumed one's responsibilities, the atmosphere with- in the Executive was extremely friendly and constructive. He wished his successor, Maurice Jacob of the Theory Division at CERN every success for his Presidency. No proposals had been received by the Executive Committee up to the Friday evening, over and above those announced earlier following the procedure agreed in Council last year of having a wide consultation. The same procedure also calls for the Vice-President to become a candidate for the next President. A further recommendation relating to the procedure for electing the Executive Committee was put forward by J.M. Irvine. It entails having Council make recommendations before the Executive Committee puts forward its proposals, but this would be difficult to implement.

A formal vote gave near unanimous endorsement of the appointments to the next Executive Committee listed below. Dates for future Council Meetings (see below) were also agreed.

\title{
Decisions of EPS Council
}

At its meeting on 24-25 May 1991, the Council of EPS made the following decisions:

- To accept the budget for 1991 that seeks an estimated surplus of about $60 \mathrm{kSFR}$.

- To increase the unit fee from the current level of 12 SFR to 13.50 SFR, taking effect on 1 January 1992.

- To accept the Executive Committee's suggestion that the proposal to index the unit fee to the inflation rate in Switzerland be withdrawn.

- To strongly recommend that the Executive Committee present restructuring proposals at the 1992 Council Meeting that include financing arrangements for 1993 and beyond, when the Executive Secretary returns to Geneva.

- To accept 420 new Individual Ordinary Members and 7 new Associate Members.

- To maintain the existing cooperation with the European Science Foundation for organizing European Study Conferences in physics, but to allow Divisions to hold Europhysics Study Conferences independently if necessary.

- To support an initiative of the Working Group on Professional Qualifications to establish the status of, and requirements for, a qualification scheme throughout Europe.

- To support an initiative of the Working Group on Student Mobility to prepare and negotiate a Convention for a European Mobility Scheme for Physics Students, pending final approval by Council and implementation.

- To endorse the activities of the East/West Task Force, noting that efforts to attract funding should be coordinated.

- To seek the agreement of the members of the Quantum Optics Division to expand the activities and interests of the Division, in collaboration with other Divisions, with the aim of integrating optical physics.

- To encourage the incoming President of EPS to develop the full range of interests of the Astronomy and Astrophysics Division, while ensuring that the Division and the European Astronomical Society work in harmony.

- To strongly recommend that the Solar Physics Section temporarily represents the Astronomy and Astrophysics Division.

- To nominate a representative of EPS to the Sub-Committee on International Scientific Affairs of the American Physical Society.

- To authorize the Executive Committee to discuss with each of the Divisions the interest in nominating a Board Member responsible for contacts with equivalent bodies in the American Physical Society.

- To authorize the retiring President to make a written submission to the SERC Review Panel on the future of nuclear structure physics in the UK.

- To elect as the Executive Committee for the year 1991/92 the following:

President: M. Jacob, Geneva

Vice-President: N. Kroo, Budapest

Secretary: H. Ryde, Lund

Vice-Secretary: A. Taroni, Brescia

Treasurer: Ph. Choquard, Lausanne

Vice-Treasurer: I. Slaus, Zagreb

- To hold future Council Meeting as follows:

1992: 27-28 March, Athens 1995: 31 March-1 April, Berlin or Bad Honnef 1993: 26-27 March, Nice

1994: 25-26 March, Warsaw
Members: A.F. Andreev, Moscow O.G. Folberth, Stuttgart

D. Horn, Tel-Aviv

E. Jakeman, Malvern

C. van der Leun, Utrecht

J. Pozhela, Vilnius 1996: 29-30 March, Lisbon 